\title{
Hva er en indremedisinsk intensivavdeling?
}

\author{
Det finnes få indremedisinske intensivavdelinger i Norge. Med et stadig økende behov for intensivplasser \\ og med sykehusstrukturer i endring er det viktig å vite hva slags pasienter som trenger indremedisinsk inten- \\ sivmedisin i et stort sykehus. Denne heterogene gruppen preges av sammensatte problemstillinger og bety- \\ delig komorbiditet, noe som fordrer bredt tverrfaglig samarbeid, både diagnostisk og terapeutisk, og riktig \\ organisering av driften.
}

Andelen eldre i den norske befolkningen øker stadig. Beregninger viser at denne endringen kan medføre et økt behov for intensivsenger på $26-37 \%$ fra 2008 frem mot 2025 (1). Parallelt med ny og bedret behandling for stadig flere sykdommer, eksempelvis innen kreft og hjerneslag, blir det også en økning i komplikasjoner som krever intensivbehandling.

I mange land er intensivmedisin en egen spesialitet, mens det i Norge stort sett er anestesileger som tar hånd om denne heterogene pasientgruppen. Omtrent halvparten av intensivpasientene er ikke-kirurgiske, og denne andelen økte fra $46 \%$ i 2006 til $55 \%$ i 2009 (2). Dette fordrer både tverrfaglighet og økt intensivmedisinsk kunnskap også hos ikke-anestesiologer (3). Det er få intensivavdelinger i Norge der man kun behandler medisinske pasienter, og det finnes lite informasjon om hvilke pasientgrupper som utgjør hovedtyngden ved en ren indremedisinsk intensivavdeling. Vi ønsket derfor å kartlegge pasientpopulasjonen i Medisinsk intensiv- og overvåkingsenhet ved Oslo universitetssykehus, Ullevål, gjennom ett år (fra april 2008 til april 2009). Avdelingen består av to tett samarbeidende enheter: medisinsk intensiv, med seks fullverdige intensivplasser, og overvåkingsseksjonen, med inntil fem plasser.

Fordi det for tiden gjøres store endringer i sykehusstrukturene flere steder og det til enhver tid foregår en debatt rundt organiseringen av intensivvirksomheten i Norge, antar vi at resultatene er interessante også utover vår avdeling.

Pasientflyten er vist i figur 1 . Forholdet regionsykehus-/lokalsykehuspasienter $\mathrm{i}$ intensivdelen var 60/40. Gjennomsnittlig liggetid i medisinsk intensiv var 5,5 døgn, noe over den i regionsykehusene generelt (4,7 døgn), mens overvåkingsseksjonen, med 2,1 døgn, hadde noe lavere liggetid enn intensivavdelingene i lokalsykehus (3,3 døgn) (2). Beleggsgraden var $94 \%$ i medisinsk intensiv og $99 \%$ i overvåkingsseksjonen. Etter korreksjon for pasienter med særlig kort liggetid var beleggsgraden henholdsvis $90 \%$ og $84 \%$.

De vanligste hoveddiagnosene var sepsis (18\%), epilepsi/kramper (10\%) og forgiftning $(9 \%)$. Totalt var infeksjon hoveddiagnose hos $30 \%$ (oftest fra luftveiene). De

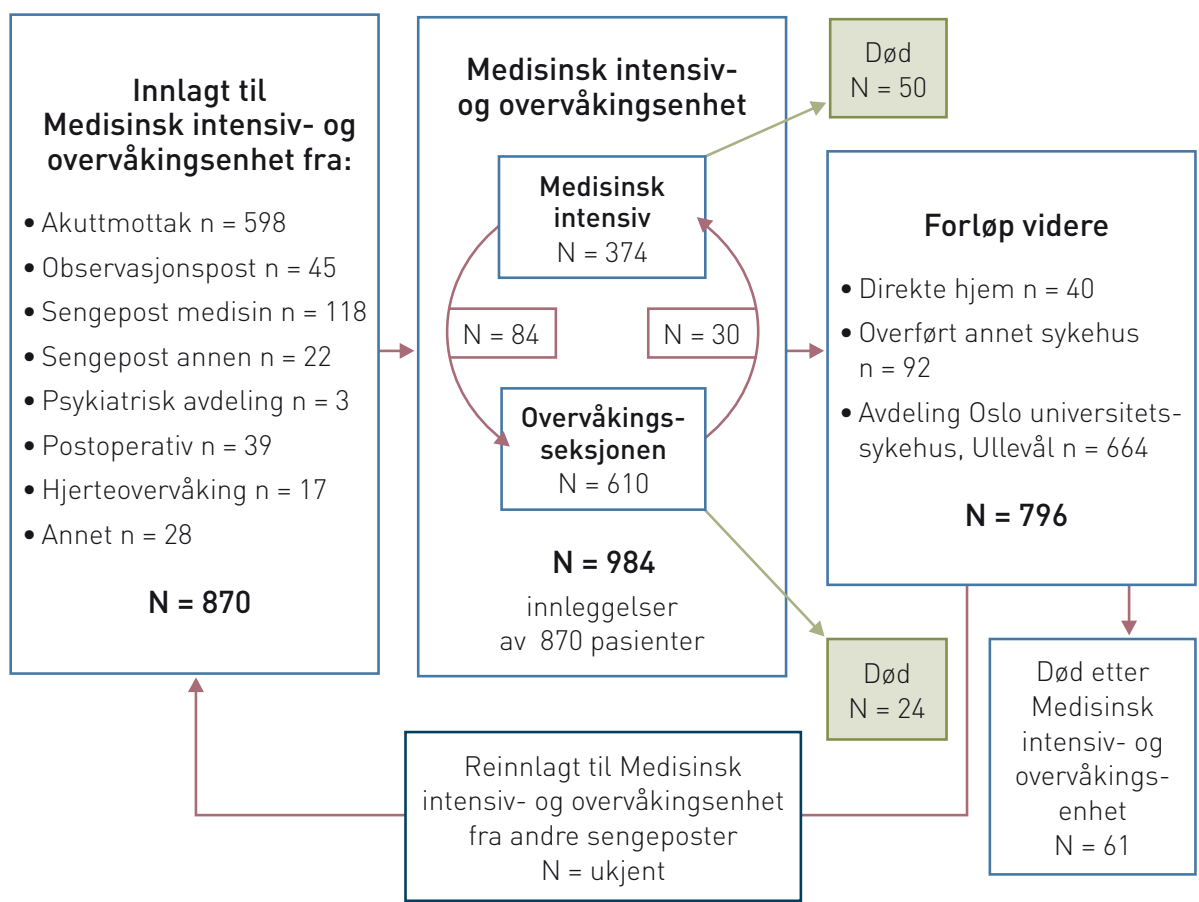

Figur 1 Pasientflyten ved Medisinsk intensiv- og overvåkingsenhet ved Oslo universitetssykehus, Ullevål, fra april 2008 til april 2009 hyppigste bidiagnosene var respirasjonssvikt (30\%), annen hjertesykdom (21\%), pneumoni (18\%), metabolske forstyrrelser (15\%) og nyresvikt (14\%). En eller flere kroniske sykdommer ble registrert hos $90 \%$ av pasientene - bare $10 \%$ ble registrert som tidligere friske. Hyppigste kjente kroniske lidelser var hjerte- og karsykdom (33\%), nevrologisk sykdom (33\%), hypertensjon (29\%) og lungesykdom (26\%).

Simplified Acute Physiology Score (SAPS II) og dødelighet var sammenliknbare med resultatene fra andre intensivavdelinger som rapporterer til Norsk intensivregister (NIR). I 2009-tallene herfra er andelen ikke-kirurgiske pasienter lavere jo høyere sykehusnivå, med kun $28 \%$ på regionnivå, mot $70 \%$ på lokalsykehusnivå (2). Dette kan skyldes overvekt av komplisert kirurgi og traumer som funksjonsfordeles eller henvises til større sykehus, mens indremedisinske lidelser i større grad behandles lokalt, til tross for at man antar at disse pasientene har mer multimorbiditet (2).

Beleggsgraden er betydelig høyere i vår avdeling enn det som er rapportert fra amerikanske intensivavdelinger, med $43 \%$ i små og $75 \%$ i store sykehus. Vår beleggsgrad ligger også over amerikanske retningslinjer, som anbefaler 80-85 \% (4). Det høye belegget underbygger den påståtte mangelen på intensivplasser i Østlandsområdet (5). Erfaringene med at overvåkingsseksjonen fungerer som en buffer for intensivavdelingen, er meget gode. Pasienter som er ute av intensivoppholdet, men som er for dårlige til å ligge på en vanlig sengepost, kan flyttes til overvåkingsseksjonen for raskt å kunne gi plass til nye intensivtrengende pasienter. At overgangen til vanlig sengepost blir mykere, er et bidrag til pasientsikkerheten.

Vi har to hovedbudskap basert på vår gjennomgang. For det første at indremedisinske intensivpasienter er en heterogen pasientgruppe med komplekse og sammensatte sykdommer. Det er en høy andel med kroniske sykdommer og behov for bred diagnostisk og terapeutisk tilnærming. De intensivmedisinske og indremedisinske utfordringene krever samarbeid på tvers av spesialitetene for å møte kravene til god diagnostikk og behandling. Vi mener derfor at det i store sykehus bør finnes intensivenheter med bred indremedisinsk kompetanse 
i tillegg til intensivmedisinsk kompetanse. For det andre viser de høye beleggstallene våre en effektiv bruk av intensivressursene. $\mathrm{Vi}$ tror at forutsetningene for dette ligger i organiseringen med en tilstrekkelig stor intermediæravdeling, og mener at en slik ordning i tilknytning til alle større intensivavdelinger bør tilstrebes.

\section{Fridtjof Heyerdah}

frihey@online.no

Akuttmedisinsk avdeling

Medisinsk klinikk

Oslo universitetssykehus, Ullevål

\section{Silje Olin Lervåg*}

Margrete Skagestad*

Medisinsk fakultet

Universitetet i Oslo

\section{Dag Jacobsen}

Akuttmedisinsk avdeling

Medisinsk klinikk

Oslo universitetssykehus, Ullevål

* Nåværende adresser:

S.O. Lervåg, Sykehuset Vestfold

M. Skagestad, Universitetssykehuset Nord-Norge, Narvik
Fridtjof Heyerdahl (f. 1970) er spesialist

i anestesiologi og overlege ved Akuttmedisinsk avdeling, Oslo universitetssykehus, Ullevål.

Forfatter har fylt ut ICMJE-skjemaet og oppgir ingen interessekonflikter.

Silje Olin Lervåg (f. 1983) er turnuslege ved Sykehuset i Vestfold.

Forfatter har fylt ut ICMJE-skjemaet og oppgir ingen interessekonflikter.

Margrete Skagestad (f. 1984) er turnuslege ved Universitetssykehuset Nord-Norge, Narvik. Forfatter har fylt ut ICMJE-skjemaet og oppgir ingen interessekonflikter.

Dag Jacobsen (f. 1952) er spesialist i klinisk farmakologi, i indremedisin og i hjertesykdommer. Han er avdelingsleder ved Akuttmedisinsk avdeling, Oslo universitetssykehus, Ullevål, og professor ved Universitetet i Oslo. Forfatter har fylt ut ICMJE-skjemaet og oppgir ingen interessekonflikter.

\section{Litteratur}

1. Laake JH, Dybwik K, Flaatten HK et al. Impact of the post-World War II generation on intensive care needs in Norway. Acta Anaesthesiol Scand 2010; 54: 479-84.

2. Kvale R. Norsk intensivregisters årsrapporter 2011. www.intensivregister.no/Annet/ \%C3\%85rsrapportar/tabid/55/Default.aspx (16.2.2012).

3. Flaatten H, Søreide E. Intensivmedisin i Norge. Tidsskr Nor Legeforen 2010; 130: 166-8.

4. Halpern NA, Pastores SM, Thaler HT et al. Changes in critical care beds and occupancy in the United States 1985-2000: differences attributable to hospital size. Crit Care Med 2006; 34: 2105-12.

5. Haugli A. mangler tittel. Dagens Næringsliv 15.10.2011.

Mottatt 13.1. 2012, første revisjon innsendt 7.2. 2012, godkjent 16.2. 2012. Medisinsk redaktør Are Brean. 